\title{
United States - Section 129(c)(1) of the Uruguay Round Agreements Act (WTO Doc. WT/DS22/R of 15 July 2002): Beating Around (The) Bush
}

\author{
BY \\ KYLE BAGWELL* \\ Columbia University and NBER \\ AND \\ PETROS C. MAVROIDIS* \\ Columbia Law School, University of Neuchâtel and CEPR
}

\section{The Factual And Legal Issues}

In this dispute, Canada attacks Section 129(c)(1) of the US trade legislation as a result of the entry into force of the Uruguay Round Agreements [Uruguay Round Agreements Act (URAA), hereinafter "Section 129"] which provides that a new antidumping or countervailing duty determination made by the Department of Commerce (DOC) or the International Trade Commission (ITC) to bring a previous antidumping, countervailing duty or injury determination into conformity with an adverse WTO panel or Appellate Body report applies only to imports that enter the United States on or after the date that the United States Trade Representative (USTR) directs implementation of the new determination.

Section 129 reads:

EFFECTS OF DETERMINATIONS. - Determinations concerning title VII of the Tariff Act of 1930 that are implemented under this section shall apply with respect to unliquidated entries of the subject merchandise

* We would like to thank all ALI reporters to this project and especially Jasper-Martijn Wauters for their many very valuable comments on previous drafts of this study. 
(as defined in section 771 of that Act) that are entered, or withdrawn from warehouse, for consumption on or after -

(A) in the case of a determination by the Commission under subsection (a) (4), the date on which the Trade Representative directs the administering authority under subsection (a)(6) to revoke an order pursuant to that determination, and

(B) in the case of a determination by the administering authority under subsection (b)(2), the date on which the Trade Representative directs the administering authority under subsection (b)(4) to implement that determination.

Canada claims that Section 129 implies that imports that entered the United States prior to that date, and that are subject to an order imposing potential liability for the payment of antidumping or countervailing duties, remain subject to future administrative review determinations and definitive duty assessment without regard to the new determination made by the Department of Commerce or the ITC and any consequent revocation or amendment of the original order.

Canada refers to imports of this kind as prior unliquidated entries. Such imports entered the United States prior to the date on which the USTR directs implementation of a new determination pursuant to Section 129(a)(6) and Section 129(b)(4) and remain unliquidated (that is, the definitive duty, if any, to be levied on the imports remains undetermined) on that date.

Canada makes two categories of claims: first, Canada claims that Section 129 as such, that is, the legislative text independently of any application, violates the WTO Agreement; second, Canada claims that Section 129, independently of any application, has the effect of violating the WTO Agreement. Canada claims that both categories of claims establish a violation of the same legal provisions in the WTO contract for the same grounds. The legal provisions are:

(a) Article VI:2, VI:3 and VI:6(a) of the GATT 1994;

(b) Articles 1, 9.3, 11.1 and 18.1 of the WTO Agreement on Antidumping (“AD Agreement");

(c) Articles 10, 19.4, 21.1 and 32.1 of the WTO Agreement on Subsidies and Countervailing Measures ("SCM Agreement");

(d) Canada further submits that, in view of the fact that Section 129 is inconsistent, in its view, with the aforementioned provisions of the AD Agreement, the SCM Agreement and the GATT 1994, Section 129 is also inconsistent with Article 18.4 of the AD Agreement, 
Article 32.5 of the SCM Agreement and Article XVI:4 of the WTO Agreement, because these provisions require that a Member's laws be in conformity with its WTO obligations as of the entry into force of the WTO Agreement.

The legal grounds are reproduced in $\S \S 6.31$ and 6.32 of the report. ${ }^{1} \mathrm{We}$ quote:

6.31 First of all, Canada asserts that section 129(c)(1) "requires", or has the effect of "requiring", the Department of Commerce:

to conduct administrative reviews with respect to "prior unliquidated entries" after the implementation date pursuant to an antidumping or countervailing duty order found by the DSB to be WTO-inconsistent;

to make administrative review determinations regarding dumping or subsidization with respect to "prior unliquidated entries" after the implementation date pursuant to an antidumping or countervailing duty order found by the DSB to be WTO-inconsistent;

to assess definitive antidumping or countervailing duties with respect to "prior unliquidated entries" after the implementation date pursuant to an antidumping or countervailing duty order found by the DSB to be WTO-inconsistent; and

to retain cash deposits in respect of "prior unliquidated entries" after the implementation date at a level found by the DSB to be WTO-inconsistent.

6.32 Canada alleges, furthermore, that section 129(c)(1), by "precluding" particular actions, infringes the WTO provisions identified by Canada. Specifically, Canada asserts that section 129(c)(1) "precludes", or has the effect of "precluding", the Department of Commerce from:

making administrative review determinations regarding dumping or subsidization with respect to "prior unliquidated entries" after the implementation date in a manner that is consistent with an adverse DSB ruling;

assessing definitive antidumping or countervailing duties with respect to "prior unliquidated entries" after the implementation date in a manner that is consistent with an adverse DSB ruling; and

${ }^{1}$ Unless otherwise indicated, every time we refer to particular paragraphs throughout this report, we refer to paragraphs of the panel report WTO Doc. WT/DS221. 
refunding, after the implementation date, cash deposits collected on "prior unliquidated entries" pursuant to an antidumping or countervailing duty order found by the DSB to be WTO-inconsistent.

(emphasis in the original).

\section{The Panel's Evaluation}

\subsection{The order of examining the various claims}

The Panel first explained that it would entertain Canada's claims under Art. 18.4 AD and 32.5 SCM only if Canada had first successfully established a violation with respect to its other claims. In the Panel's view this way of proceeding was legitimized by the fact that, in Canada's view, Arts. 18.4 AD and 32.5 SCM respectively are ipso facto violated in case the other violations have been established. It goes without saying that were the Panel to find that Canada did not establish violation with respect to the other claims, its claims under Arts. 18.4 AD and 32.5 SCM would fall.

\subsection{Section 129 as such requires WTO-inconsistent behavior}

\subsubsection{The legal benchmark to establish a violation}

The Panel lays out its legal benchmark to establish that Section 129 as such amounts to a violation of the WTO Agreement in $\S 6.22$ of the report in the following terms:

It is clear to us that a Member may challenge, and a WTO panel rule against, a statutory provision of another Member "as such" (for example, section 129(c)(1)), provided the statutory provision "mandates" the Member either to take action which is inconsistent with its WTO obligations or not take action which is required by its WTO obligations.

Then the Panel, following the standing rules in WTO law for allocation of burden of proof (the complainant carries the initial burden of proof), goes on to hold that $(\S 6.23)$ :

... it will be clear that Canada's principal claims will be sustained only if Canada succeeds in establishing that section 129(c)(1) mandates the United States to take action which is inconsistent with the WTO provisions which form the basis for those claims or mandates the United States not to take action which is required by those WTO provisions. In other words, for Canada to discharge its burden with respect to its principal claims, it must demonstrate both of two elements: first, that section 129(c)(1) mandates 
that the United States take or not take the action identified by Canada, and second that this mandated behaviour is inconsistent with the WTO provisions that it has invoked.

(emphasis in the original).

The Panel notes, however, that it is not going to examine Section 129 in clinical isolation from the potentially relevant other US legal framework. To this effect, the Panel, as other panels did before, singles out the Statement of Administrative Action (SAA) which is included in the URAA. In the Panel's view, the SAA is relevant for the interpretation of Section 129, a point to which Canada itself has not objected. We quote from $\S \S 6.36$ (Canada's understanding of the relationship between the SAA and Section 129 - a point not challenged by the US) and 6.38 (the Panel's understanding of the relationship):

The SAA sets forth the authoritative interpretation of the URAA and the US Administration's obligations in implementing the URAA, as agreed between the US Administration and the US Congress. Congress approved the SAA in section 101 of the URAA and provided, in section 102 of the URAA, that " $[\mathrm{t}]$ he statement of administrative action approved by the Congress under section 101(a) shall be regarded as an authoritative expression by the United States concerning the interpretation and application of the Uruguay Round Agreements and this Act in any judicial proceeding in which a question arises concerning such interpretation or application".

Accordingly, in our examination of section 129(c)(1), we must be mindful of the legal status of the SAA in US law and take account of its content. This said, two caveats should be noted. First, it should be remembered that section 129(c)(1) is to be interpreted in the light of the SAA, and not the other way round. Second, it should be recalled that, even though the SAA is intended to shed light on the meaning of the various provisions of the URAA, the statements contained in the SAA may, themselves, be open to interpretation.

(emphasis in the original).

The SAA is reflected in $\S 6.40$ of the report. We quote:

Consistent with the principle that GATT panel recommendations apply only prospectively, subsection 129 (c)(1) provides that where determinations by the ITC or Commerce are implemented under subsections (a) or (b), such determinations have prospective effect only. That is, they apply to unliquidated entries of merchandise entered, or withdrawn from warehouse, for consumption on or after the date on which the Trade Representative 
directs implementation. Thus, relief available under subsection 129(c)(1) is distinguishable from relief available in an action brought before a court or a NAFTA binational panel, where, depending on the circumstances of the case, retroactive relief may be available. Under 129(c)(1), if implementation of a WTO report should result in the revocation of an antidumping or countervailing duty order, entries made prior to the date of Trade Representative's direction would remain subject to potential duty liability.

Having established the context for the interpretation of Section 129 as well as the legal benchmark for establishing a violation, the Panel turned to examine Canada's claims.

\subsubsection{What does Section 129 actually do?}

It is clear from the text of Section 129 that it applies to AD and countervailing (CVD) duties perceived by the competent US authorities ( $§ 6.48$ ). Probably the best way to explain what Section 129 actually does is through an example. But before we do that, we should first spend some time understanding how the US system for calculation of dumping margins operates in practice.

The US is one of the few countries that practice the so-called retrospective duty assessment mechanism. Most other WTO Members, including Canada and the European Community, use the prospective duty assessment mechanism. Under the former, the investigating authority determines the amount of the duty at the end of the investigation period. Such determination, however, serves only as a provisional basis for the collection of cash deposits. Assume for example, that the US conclude their investigation on 1.1.2001 and find that the dumping margin for imports of good X from country Y is $30 \%$. Any importer of good X from country $\mathrm{Y}$ will be required to make a cash deposit of $30 \%$ for imports occurring on or after 1.1.2001.

The final duty liability is only determined at the end of each year following imposition of the measure and after calculations based on data for the past twelve months. So on 1.1.2002 in our example, the US will recalculate the dumping margin for good $\mathrm{X}$ from country $\mathrm{Y}$ based on data from transactions occurring from 1.1.2001-1.1.2002. If the duty is higher than originally calculated, the investigating authority will request additional duties to be paid. If it is lower, the investigating authority will release the part of the deposits that was not due.

At the same time, this newly calculated duty rate will constitute the estimated rate on the basis of which provisional duties in the form of cash deposits will be imposed. And so on, and so forth. 
By contrast, the duty rate will, in the context of the prospective duty assessment mechanism, be calculated at the end of the period of investigation and will be applied to all future imports (although the possibility exists for interested parties to demonstrate that the actual dumping margin was less and hence be reimbursed). Final liability, however, is determined before imports enter the country, leaving aside the possibility of reimbursement or judicial review which are institutional mechanisms quite different from the actual duty assessment.

Canada's argument is that the final liability in the retrospective duty assessment mechanism will only be determined after the imports have entered the country. To go back to our hypothetical: assume that a WTO panel finds on 1.1.2002 that the US had wrongfully calculated the dumping margin and that actually, following a new correct calculation, the US should have ended up with a smaller figure. Imports between 1.1.2001 and 1.1.2002 for which no final determination has been made, will still have to be burdened by the $30 \%$ dumping margin because of Section 129 .

In Canada's view, this is not an issue for WTO Members which apply the prospective duty assessment mechanism, since such Members apply duties only following a final determination and there is no uncertainty as to the duty that will be finally paid.

It stems from the above that effectively Canada is not arguing that Section 129 is a barrier towards providing retrospective remedies. Rather, Canada's argument is much more narrow: the point is that in Canada's view even a prospective remedy recommended by the WTO would oblige a country which follows the retrospective duty assessment mechanism to apply the new WTO-consistent methodology to all transactions that took place in the previous year because no final determination has been made with respect to such transactions. The same, by inference, would not be the case when a country applies a prospective duty assessment mechanism, since a prospective WTO remedy will be applicable only to future transactions because all past transactions have benefited from a final determination.

Canada in other words attacks the idiosyncrasy of the US system whereby no final determination has been made for past transactions until the end of each year without putting into question the issue of whether the WTO allows for retrospective remedies or not.

We should make it clear that Section 129 does not impose a time span within which the USTR must act, and Canada has made no claims to this effect. Canada's claims are that Section 129, while providing a WTOconsistent solution for all imports of good X from country $\mathrm{Y}$ as of the date 
when the USTR direction has been issued, does not provide a WTOconsistent solution for all entries prior to the date of issuance of the USTR direction (that is, the prior unliquidated entries). In Canada's view, the WTO-consistent solution would be, for example, for the US to apply to all imports which took place during the year leading to the end of the reasonable period of time within which the US must bring its laws into compliance with its WTO obligations, the rate found by the WTO adjudicating body to be the appropriate one.

The US respond that Section 129 has nothing to do with prior unliquidated entries and that their treatment will be decided in the context of a separate (but not identified in the US submissions) proceeding $(\S 6.42)$.

\subsubsection{Does Section 129 apply to prior unliquidated entries?}

The Panel, examining the wording of Section 129 in light of its context (SAA), concluded that Section 129 simply does not apply to prior unliquidated entries, the treatment of which is unaffected by the scope of Section 129 ( $\S \S 6.53$ and 6.55). From there on it was all downhill: having established that Section 129 does not deal with the factual issue identified in Canada's submission, the Panel naturally concluded that Canada did not observe its burden of proof and consequently did not establish a violation of the WTO Agreement.

\subsubsection{Concluding remarks}

It follows from the discussion under 2.2.3 that the Panel rejected Canada's claims that Section 129 requires from US domestic authorities WTOinconsistent behavior.

\subsection{Section 129 precludes or has the effect of precluding WTO-consistent behavior}

\subsubsection{The legal benchmark to establish a violation}

Unsurprisingly, the Panel adopts the same legal benchmark as when examining the first category of claims, with one notable difference: in this context, the Panel makes it clear that all its findings are provisional and will become final only after examining Canada's claims under the explicit wording of SAA. The Panel of course interpreted Section 129 in the context of the SAA after the first category of claims as well; it did not, however, make the distinction between provisional and final findings in 
that context. The Panel explained the different approach in $\S 6.58$ of its report in the following terms:

We will first examine the arguments of the parties relating to section 129 (c)(1) as enacted. After that, we will consider the parties' arguments concerning relevant portions of the SAA. We wish to be clear that we assess these arguments separately for convenience of analysis only. As we have noted, section 129(c)(1) must be read together with the SAA. Accordingly, we will not reach any conclusions regarding Canada's assertions that section 129(c)(1) has the effect of requiring and precluding certain actions until after we have taken into account relevant parts of the SAA. Our conclusions regarding the assertions in question will, as a result, be based on section 129(c)(1) as interpreted by the SAA, rather than on section 129(c)(1) read in isolation. Moreover, before reaching any conclusions regarding Canada's assertions, we will also address the application of section $129(\mathrm{c})(1)$ to date.

Implicit in this statement is that the fact that Canada, with respect to this category of claims, argued that Section 129 not only precludes but further has the effect of precluding WTO-consistent behavior justifies the current approach. The Panel examined Canada's claims with respect to methodology and revocation cases, as argued by the complaining party. We take each claim in turn.

\subsubsection{Section 129 and methodology cases}

Canada's claims with respect to methodology cases are discussed in $\S \S 6.67-6.81$. In $\S 6.67$, the Panel explains its understanding of the term methodology cases in pertinent, self-explanatory terms:

\footnotetext{
Methodology cases are cases in which the section 129 determination does not result in the revocation of the original antidumping or countervailing duty order, but instead results in a new margin of dumping or a new countervailable subsidy rate. Such an outcome may be due, for instance, to the application of a new, WTO-consistent methodology or a new, WTOconsistent interpretation of US antidumping or countervailing duty laws.
}

The Panel, applying the same logic as with respect to the first category of cases, concludes that Section 129 does not deal with prior unliquidated entries that qualify as methodology cases ( $\S 6.68$ of the report). This, in the Panel's view, means that the US competent authority (the Department of Commerce, DOC) is not required to continue to perceive the same amount of duties independently of changes as a result to the new, applicable methodology ( $\S 6.69$ of the report); on the other hand, it does not 
automatically follow that because Section 129 does not deal with prior unliquidated entries, the DOC is precluded from applying to such transactions the treatment it applies to transactions post-direction by the USTR ( $\S 6.72$ of the report).

The Panel finds support in its argument when it examines Canada's arguments that the US intended to permit temporary retention of extensive cash deposits through Section 129. In the Panel's view, the exact opposite seems to have been the intention of the US Congress: to ensure compliance with WTO rulings affecting transactions that are not what Canada terms prior unliquidated entry. As a result, no US court would, in the Panel's view, interpret Section 129 as suggested by Canada ( $\S 6.76$ of the report).

The Panel finds further support in its line of reasoning when interpreting Section 129 in the light of the SAA ( $\S$ 99-114). The Panel notes that there is no judicial interpretation of Section 129 which contradicts its understanding and that the only administrative interpretation available is simply irrelevant for the purposes of the present dispute ( $\S \S 6.115$ and 6.118 respectively).

\subsubsection{Section 129 and revocation cases}

The Panel then moves to examine the revocation cases ( $\S \S 6.82-6.92)$. The Panel first defines revocation cases in the following manner ( $\S 6.82)$ :

Revocation cases are cases in which the section 129 determination results in the revocation of the original antidumping or countervailing duty order. An antidumping or countervailing duty order would be revoked if a section 129 determination established that there was no dumping, no subsidization or no injury. Pursuant to section 129(c)(1), the revocation of a WTO-inconsistent antidumping or countervailing duty order would apply to all entries that take place on or after the implementation date. We are led to understand that, in practice, this would mean that, as of the implementation date, cash deposits would no longer be required on new entries.

In Canada's view, Section 129 precludes or has the effect of precluding the US from applying the same standard to prior unliquidated entries. The Panel dismisses Canada's claims in the following manner ( $\S \S 6.83-6.84$ ):

As we see it, since, pursuant to section 129(c)(1), a section 129 determination of this type would not be applicable to "prior unliquidated entries", that determination, as such, would not have an impact on "prior unliquidated entries". In other words, we think it can be inferred from the fact that 
a revocation of an antidumping or countervailing duty order would apply only with respect to post-implementation entries that the Department of Commerce would not be required, because of section 129(c)(1), to refund cash deposits previously collected on "prior unliquidated entries" on the basis of the WTO-inconsistent antidumping or countervailing duty order, to decline to conduct administrative reviews for such entries, to decline to make determinations regarding dumping or subsidization with respect such entries on the basis of the WTO-inconsistent antidumping or countervailing duty order or to decline to assess definitive antidumping or countervailing duties with respect to such entries on the basis of the WTO-inconsistent antidumping or countervailing duty order.

Conversely, we think it can not be inferred from the mere fact that a revocation is inapplicable to "prior unliquidated entries" that the Department of Commerce would be required to retain cash deposits collected on such entries on the basis of the WTO-inconsistent antidumping or countervailing duty order or would be precluded from refunding such cash deposits. Nor does it follow from the fact that a revocation does not apply to "prior unliquidated entries" that the Department of Commerce would be required to conduct administrative reviews for such entries. Nor does the non-application of a revocation to "prior unliquidated entries" necessarily imply that the Department of Commerce would be required to make administrative review determinations regarding dumping or subsidization and assess definitive antidumping or countervailing duties with respect to "prior unliquidated entries" on the basis of the WTO-inconsistent antidumping or countervailing duty order, or would be precluded from making such determinations and assessing definitive duties with respect to such entries in a manner consistent with WTO requirements.

Canada, in its effort to persuade the Panel, offered a counterfactual: in the absence of Section 129, the US would be obliged to revoke all transactions, that is prior unliquidated entries as well. The Panel dismissed this argument and offered a very narrow construction of the counterfactual $(\S 6.88)$ :

Indeed, if there were no section $129(\mathrm{c})(1)$ and a provision like section 129(c)(1) was subsequently enacted, the consequence of this would be that section 129 determinations would not apply to "prior unliquidated entries". As we have said, this would mean that the Department of Commerce would then not be required, as a matter of US law, to return cash deposits collected on such entries based on the WTOinconsistent antidumping or countervailing duty order, to decline to hold administrative reviews for such entries and to decline to assess duties with 
respect to such entries on the basis of the WTO-inconsistent order. Moreover, as we have also observed, it would not follow from the fact that a revocation would then be inapplicable to "prior unliquidated entries" that the Department of Commerce could not return cash deposits collected on "prior unliquidated entries" could not decline to hold administrative reviews with respect to such entries and could not decline to assess duties with respect to such entries.

\subsubsection{Concluding remarks}

The Panel hence concluded that Canada did not establish a prima facie case that the US Section 129 was WTO-inconsistent and consequently, rejected Canada's claims in this respect as well. The Panel thus also rejected Canada's claims under Arts. 18.4 AB and 32.5 SCM.

\section{Evaluation}

\subsection{Mandatory vs. discretionary legislation}

The WTO case law on the legal benchmark to be applied by adjudicating bodies when entertaining claims that a legislation as such is WTOinconsistent is not a monument of clarity. For years, adjudicating bodies repeated the statement that, unless the complainant shows that the (any) legislation mandates WTO-inconsistent behavior, it cannot successfully absolve its burden of proof. Then came the panel report on United States Sections 301-310 of the Trade Act of 1974 (WTO Doc. WT/DS152/R of 22 December 1999) which held that some provisions of WTO treaties may give rise to state responsibility to ensure that even legislation that has discretionary elements does not give rise to a threat or serious likelihood of a WTO violation:

Article 23 may prohibit legislation with certain discretionary elements and therefore the very fact of having in the legislation such discretion could, in effect, preclude WTO consistency

(§ 7.54 of the report, op. cit).

Hence, the distinction between discretionary and mandatory legislation is not, in this panel's view, as such determinative of state responsibility. State responsibility ultimately flows from the particular nature of the treaty provisions at issue, and must be interpreted accordingly.

Subsequently, the Appellate Body report on United States - Antidumping Act of 1916 (WTO Doc. WT/DS136\&162/AB/R of 28 August 2000 at 
$\S \S 89-91)$ approves in a footnote the finding of the Section 301 panel that some kinds of discretionary legislation might give rise to treaty violations in certain circumstances. It further held that only discretion vested in the executive branch of the government matters for the purposes of this distinction. In the case at hand, the US Department of Justice enjoyed some discretion to initiate or not criminal proceedings. In the words of the Appellate Body, however, such discretion was not

of such a nature or of such a breadth as to transform the 1916 Act into discretionary legislation, as this term has been understood for purposes of distinguishing between mandatory and discretionary legislation.

The issue took another twist in the Appellate Body report on United StatesSection 211 Omnibus Appropriations Act of 1998 (WTO Doc. WT/DS 176/ $A B / R$ of 2 January 2002). There the Appellate Body faced the argument by the EC that the US legislation, the discretionary character of which was acknowledged in the panel report, was imposing an "extra hurdle" on foreign nationals in violation of the national treatment obligation protected under the TRIPs Agreement. It reacted in the following manner and reversed the panel's findings that the legislation at hand, because discretionary, could not be scrutinized by a WTO adjudicating body. We quote from $\S \S 256,259-260$ and 267-269:

That "extra hurdle" is this. United States nationals who are successorsin-interest must go successfully only through the OFAC procedure. In the circumstances addressed by Section 211, they are not subject to the constraints imposed by Section 211(a)(2). In contrast, non-United States successors-in-interest not only must go successfully through the OFAC procedure, but also find themselves additionally exposed to the "extra hurdle" of an additional proceeding under Section 211(a)(2). In sum, United States nationals face only one proceeding, while non-United States nationals face two. It is on this basis that the European Communities claims on appeal that Section 211(a)(2), as it relates to successors-in-interest, violates the national treatment obligation in the TRIPS Agreement and the Paris Convention (1967).

... As the Panel rightly noted, in US - 1916 Act, we stated that a distinction should be made between legislation that mandates WTO-inconsistent behaviour, and legislation that gives rise to executive authority that can be exercised with discretion. We quoted with approval there the following statement of the panel in US - Tobacco: 
... panels had consistently ruled that legislation which mandated action inconsistent with the General Agreement could be challenged as such, whereas legislation which merely gave the discretion to the executive authority of a contracting party to act inconsistently with the General Agreement could not be challenged as such; only the actual application of such legislation inconsistent with the General Agreement could be subject to challenge.

Thus, where discretionary authority is vested in the executive branch of a WTO Member, it cannot be assumed that the WTO Member will fail to implement its obligations under the WTO Agreement in good faith. Relying on these rulings, and interpreting them correctly, the Panel concluded that it could not assume that OFAC would exercise its discretionary executive authority inconsistently with the obligations of the United States under the WTO Agreement. Here, too, we agree.

But here, the Panel stopped. We are of the view that, having reached the conclusion it did with respect to the offsetting effect of OFAC practice, the Panel should not have stopped but should have gone on and considered the argument made by the European Communities about the "extra hurdle" faced by non-United States successors-in-interest. For this reason, we do so now.

The United States has not shown, as required under the national treatment obligation, that, in every individual case, the courts of the United States would not validate the assertion of rights by a United States successorin-interest. Moreover, even if there is, as the United States argues, a likelihood that United States courts would not enforce rights asserted by a United States successor-in-interest, the fact remains, nevertheless, that non-United States successors-in-interest are placed by the measure, on its face, in an inherently less favourable situation than that faced by United States successors-in-interest. And, even if we were to accept the United States argument about the doctrine of non-recognition of foreign confiscation, presumably that doctrine would apply to those who are not nationals of the United States as well as to those who are. Any application of this doctrine would therefore not offset the discrimination in Section 211(a)(2), because it would constitute yet another, separate obstacle faced by nationals and non-nationals alike. Hence, it would not offset the effect of Section 211(a)(2), which applies only to successors-in-interest who are not United States nationals.

Accordingly, we conclude that Section 211(a)(2) imposes an additional obstacle on successors-in-interest who are not nationals of the United States that is not faced by United States successors-in-interest. And, therefore, we conclude that, by applying the "extra hurdle" imposed by 
Section 211(a)(2) only to non-United States successors-in-interest, the United States violates the national treatment obligation in Article 2(1) of the Paris Convention (1967) and Article 3.1 of the TRIPS Agreement.

For this reason, we reverse the Panel's conclusion in paragraph 8.140 of the Panel Report that "[b] ecause US nationals are unable to obtain licences so as to become a successor-in-interest and OFAC has not granted any such licence for such purpose ... Section 211(a)(2) is not inconsistent with Article 3.1 of the TRIPS Agreement and Article 2.1 of the TRIPS Agreement in conjunction with Article 2(1) of the Paris Convention (1967).”

This is the latest pronouncement by the Appellate Body on the issue. The cited passage is quite cryptic in the sense that it does not clarify under what circumstances the burden of proof shifts to the defendant (in the instant case, the US) to demonstrate that national treatment will be observed in every transaction as the Appellate Body states.

The present case is a shift towards the "hard line" adopted by some WTO adjudicating bodies whereby only legislation which always mandates WTO-inconsistent behavior should be judged to be WTO-inconsistent: in a nutshell, the Panel seems to suggest that it would have found violation only in the case where the US legislation would explicitly preclude the US competent authorities from acting upon prior unliquidated entries.

The distinction between mandatory/discretionary legislation is judge-made law. The arguments advanced in its support are two-fold: by sanctioning only mandatory legislation one avoids over-burdening administratively the dispute settlement system of the WTO; on the other hand, in presence of discretionary legislation which might or might not eventually take the form of a WTO-inconsistent action, one should not rush to the conclusion that an illegality will be committed anyway (some form of application of the in dubio pro mitius maxim). Uncertainty, hence, is not punishable under this distinction.

This distinction implies that WTO Members can have the discretion to behave in a WTO-inconsistent manner and will be punished only if they do so. But retaining such discretion is at odds with the very idea of entering into a contractual regime (with substantial in-built flexibilities) where each participant promises the other WTO-consistent behavior at all times for all issues covered by the WTO in accordance with the basic pacta sunt servanda principle and Arts. 26 and 70 of the Vienna Convention on the Law of Treaties. It should be pointed out that the Section 301 case law cited above was a very honorable effort to bridge this gap by requesting WTO Members to avoid, when appropriate, uncertainty as to their behavior. 


\subsection{Prospective against retrospective duty assessment mechanisms: does it really matter?}

We have described above the two systems used by WTO investigating authorities for assessing dumping margins: the prospective and the retrospective system. Assume that an investigation occurs simultaneously in the US and the EC on allegedly dumped imports of maple leaf syrup (MLS) from Canada. Assume that both the US and the EC investigating authorities terminate their investigation on 1.1.2001 and find that Canadian MLS exporters have been dumping by $30 \%$ their exports of MLS to US and the EC. The US imposes the $30 \%$ rate provisionally and will recalculate the duty at the end of the year. They do so and on 31.12.2001 they find that Canadians continue to dump by $30 \%$ their exports of MLS to US. They hence release no funds to Canadian exporters and continue applying the $30 \%$ duty rate to all imports of MLS originating from Canada as from 1.1.2002. The EC applies as of 1.1.2001 the 30\% duty rate in an uninterrupted manner to all imports of MLS originating in Canada.

Assume further that Canada introduces two complaints before the WTO and two WTO panels find that the duty should have been $15 \%$. The panels consequently request that the US and EC bring their measures into compliance. Finally, assume that the panel is not appealed and that the reasonable period of time for both the EC and the US to bring their measures into compliance ends up on 31.12.2002.

The EC starts applying the $15 \%$ rate on all imports taking place as of 1.1.2003. In Canada's view, there is nothing wrong with such an implementation; in its view, the EC has faithfully implemented the panel's recommendations (and/or suggestions). The fact that the EC does not reimburse any duties for imports between 1.1.2001 and 1.1.2003 is not problematic in Canada's view.

The US does the same. It applies the $15 \%$ rate on all imports taking place as of 1.1.2003. Canada believes that the US has not implemented the panel's recommendations although the same transactions will be burdened by exactly the same dumping duty on the two sides of the Atlantic. The reason justifying Canada's nod to the EC implementation and Canada's nay to the US implementation is that the former applies the prospective whereas the latter the retrospective duty assessment scheme.

But should a domestic technique to assess duties matter? What matters is not how the US or the EC technically qualify the duties imposed. What matters should be which transactions should be burdened by which duty 
rate following a panel's finding that the duty had been mis-calculated in the original investigation.

It seems that Canada wants to avoid "rocking the boat" by entering into the sometimes contentious discussion of prospective vs. retroactive remedies in the WTO, but at the same time wants to benefit marginally (in the sense that it wishes to see, in case following a complaint to this effect a WTO panel finds that the US duty is excessive and requests the US to bring their measures into compliance, the WTO-consistent duty applied to all prior unliquidated entries: in case for example, a US 20\% duty is in place for 3 years, and a WTO panel finds that the duty should be $10 \%$ instead, according to Canada's argument, the prior unliquidated entries, that is all imports taking place in the last of the three years, should benefit from the $10 \%$ duty) from retroactive remedies without naming them explicitly so.

It should be kept in mind that the WTO Antidumping Agreement does not impose in this respect a particular method to be used for calculating dumping margins (Art. 9.3 AD explicitly acknowledges the possibility of calculating final duties by having recourse to either the prospective or the retrospective system): Art. 2 AD requires from WTO Members to establish a dumping margin by observing its disciplines; and Art. $10 \mathrm{AD}$ requires that in case provisional duties have been imposed and final duties are of a lesser value, then reimbursement should occur. The US system observes both these provisions.

For Canada to move and outlaw the US system, it would have to take the bold step and argue that in case a panel finds that duties should have been lower or never in place, such a recommendation (and/or suggestion) to revoke the order imposing duties should be understood as an obligation to implement retroactive remedies. In this case, the US would never be in a position to honor their WTO obligations, since the US Section 129 does not allow them to implement the WTO remedy in a retroactive manner as its unambiguous wording suggests. This is the step that Canada did not wish to take.

At the end of the day, however, irrespective of whether one qualifies a system as prospective or retroactive, the question is what is the time function of remedies? For a panel to accept Canada's argument, it would mean that the US is punished for committing crimes which would remain unpunished when committed by the EC or Canada or any WTO Member using the prospective system. Such an interpretation would run counter to the explicit acknowledgement in Art. 9.3 AD (indeed, the very provision the violation of which Canada asserted before the panel) 
that WTO Members can use either method when calculating dumping margins.

Canada was beating around the bush and the panel mimicked this dance. As we explain in what immediately follows, the panel, instead of trying to make some sense of Canada's (admittedly convoluted) arguments, beat around the bush itself, by establishing such a high burden of proof for the complainant that Canada would not be in a position to meet this burden. The panel thereby provided itself with the deus ex machina to avoid entering into a sensible understanding of Canada's claims.

\subsection{Beating around the bush: the burden of proof ploy}

The allocation of burden of proof is judge-made law: even in cases where one might intuitively presume that the burden of proof has been allocated in a particular way (like in the case of Art. 2.4 TBT), WTO adjudicating bodies have offered their own reading of the situation. GATT/WTO adjudicating bodies have more or less followed the maxims actori incumbit probatio (the party arguing something carries the burden of proof for its argument) and jura novit curia (the court of law is aware of the law applicable). From an economic perspective, it would seem that two considerations are of primordial interest when strategically allocating burden of proof:

(a) what is the objective of the adjudication?

(b) which party is best positioned to know a particular fact?

The response to (a) is quite straightforward: the WTO legal system does not know of ex officio complaints. Hence, its objective is not the discovery of the truth (however quixotic such a search might be). Its objective function is to accept or reject claims made by the participants. This is where (b) kicks in. However, since one cannot presume inconsistencies, the original burden of proof is always allocated to the complaining party. Burden of proof should be distinguished from quantum of proof: how much is needed to establish what is represented in legal terms as a prima facie case of violation is essentially a matter of appreciation by the adjudicating body (and a hardly quantifiable issue).

Let us entertain this discussion through two examples, keeping in mind that there is no dispute as to the mandatory nature of the legislation and as to the fact that Canada absolved its burden of proof in this respect. Under Scenario 1, Section 129 deals with all transactions but not with unliquidated entries, and there is another US domestic law provision which deals 
with such entries. Under Scenario 2, Section 129 deals with all transactions but not with unliquidated entries and there is no US domestic law provision dealing with such entries. ${ }^{2}$ Presumably, the Panel's approach is that the burden of proof is the same in both scenarios.

Take Scenario 1: Canada shows what Section 129 does (as it did in the instant dispute), and we assume that the quantum of proof submitted by Canada by and large suffices for Canada to absolve its burden of proof. The burden of proof shifts to the US and all they have to do is show that there is another provision which does exactly what Canada requests (that is, that there is another US law dealing with prior unliquidated entries). The burden of proof shifts to the US since the US are in a better position to know their own legal regime. The downside to such allocation of the burden of proof is that it might incite too many legal challenges. It is to be rationally expected, however, that many cases will not go beyond the consultation stage (assuming that there is an obvious response to the claim, as it is in the present hypothesis).

Take now Scenario 2. Once again, assuming that Canada has shown that the legislation at hand is mandatory, if the burden of proof shifts to the US, Canada wins.

The Panel seems to suggest that for the US law at hand to be WTOinconsistent it must not only state that it applies to post-USTR direction entries but further that it does not apply to prior unliquidated entries. The policy prescription which stems from this standard is that Canada could only complain about specific instances where prior unliquidated entries have been treated in a WTO-inconsistent manner and not about the legislation as such. But the Panel does not respond to a natural question emerging from this dispute: why would the US apply Section 129 to prior unliquidated entries when SAA, the natural legal context of Section 129 in the Panel's eyes, starts from the premise that all GATT recommendations are prospective? In this view bygones are bygones and there is nothing that one could do about them.

It seems that the Panel went out of its way to establish a very high evidentiary standard (the law must state that it applies to post-USTR direction entries and that it does not apply to prior unliquidated entries) in order to avoid discussing the issues before it. As discussed above, Canada's arguments before the Panel are not a monument of clarity and

${ }^{2}$ We assume for the study of both scenarios that Canada has proved that the legislation is mandatory. 
if at all, the basis for Canada's complaint is much narrower (consistency of the retrospective duty assessment scheme) than the Panel's appreciation of it (retroactive remedies). Probably because the Panel failed to clarify what Canada was actually complaining about or probably because there is a fine line between Canada's arguments as presented before the Panel and the issue of retroactive remedies, the Panel decided to set such discussion aside by bringing forward an admittedly high evidentiary standard.

Of course Panels, by virtue of the maxim non ultra petita, cannot rule beyond what has been requested by the parties to the dispute. Since admittedly Canada did not explicitly request a ruling on the issue whether Section 129 does not allow reimbursement of retroactive duties, the Panel could not have addressed the issue in the first place. But Canada's arguments could be interpreted as going some way towards this direction:

(a) the retrospective duty assessment scheme practiced by the US concerns final and not provisional duties (this explains why Canada did not invoke Art. $10 \mathrm{AD}$ for example);

(b) by arguing that Section 129 does not allow the US to apply the WTOconsistent regime to all imports during the last year, Canada is effectively arguing that all final duties applied on a provisional basis by the US should either be re-calculated and partially reimbursed (in a methodology case) or totally reimbursed (in a revocation case);

(c) true, Canada does not request full retroactive remedies. But Canada requests some form of retroactivity for duties perceived during the last year where imports were first burdened by a provisional and then by a definitive assessment.

Such an understanding of Canada's claims is not unthinkable in light of the arguments advanced by Canada. And it is precisely this understanding of Canada's claims that is thwarted once and for all by the panel's choice to impose such a high evidentiary standard for Canada so as to avoid entering into such a discussion.

\subsection{The remedies issue}

\subsubsection{An unresolved issue in WTO law}

The SAA starts with the premise that GATT panel recommendations apply only prospectively. As stated above, the Panel holds SAA to be the natural context (and hence relevant for the understanding and the interpretation) of Section 129. 
The Panel does not take any formal position on this issue. In fact, the Panel, as we have highlighted in the previous sub-section, goes out of its way in this report to avoid taking any position. It is true that this endeavour of the Panel was to some extent driven by the claims put forward by Canada who did not ask squarely the question of whether this premise is WTO-consistent. A very reticent panel, like this one, found easy refuge behind the Canadian arguments of rather general nature and avoided the issue.

Since the issue was not formally discussed, we will refrain from addressing it in a comprehensive manner in this report. Suffice it to say, however, that

(a) the WTO primary law does not explicitly address the time-function of remedies;

(b) GATT/WTO practice evidences both cases of prospective and cases of retroactive remedies; and

(c) from a public international law perspective, it is far from clear that GATT recommendations are prospective, and there is some GATT/ WTO panel-practice to the opposite (of the SAA) direction. ${ }^{3}$

In fact, some good economic arguments could be made in favour of introducing retroactive remedies into the WTO legal system. We turn to such arguments in what immediately follows.

\subsubsection{Prospective remedies: enjoy the benefits of cheating without} facing the costs of retaliation

In this sub-section, we first describe an economic framework within which the role of trade agreements may be understood. We then discuss remedies in the context of this framework.

We begin with a basic question: What is the purpose of a trade agreement? A satisfactory answer to this question must identify the reason that an appropriately designed trade agreement can offer governments greater political-economic welfare than they can achieve in the absence of a trade agreement (i.e., when trade policies are set unilaterally). In other words, we must identify an inefficiency (relative to governments' welfares) that arises when trade policies are set unilaterally and that is eliminated or reduced in an appropriately designed trade agreement.

3 There are five reported cases in the GATT- and one in the WTO-era where panels recommended retroactive remedies. See Mavroidis (2001). 
But what is this inefficiency? Consider a government that is evaluating whether to unilaterally impose an import tariff on some good. The government is aware that the tariff would create "winners" and "losers" in the domestic economy: the tariff would have the effect of raising the domestic price of the affected good, and so the domestic importcompeting industry would be a winner while domestic consumers would be losers. Let's suppose that, after weighing the domestic political and economic consequences of the import tariff, the government decides to impose the tariff. Notice that the government's political-economic calculation did not include the impact of the import tariff on the foreign export industry. If the import tariff lowers the profit enjoyed by foreign exporters, then the foreign export industry - and thus the foreign government is also a loser when the import tariff is imposed. When trade policies are set unilaterally, tariffs are thus inefficient and "too high," since each government does not internalize the cost of an increase in its own tariff on the welfare of the other government. ${ }^{4}$

From this perspective, it is now straightforward to see that an appropriately designed trade agreement can eliminate or reduce this inefficiency and raise the welfares of the participating governments beyond those which they would enjoy in the absence of an agreement. Reciprocity is a fundamental feature of such an agreement. A government is willing to make the concession of reducing its import tariff below its preferred unilateral level, provided that its trading partner does the same. In this general manner, a government's concern for its own export industry, in effect, motivates it to weigh in the impact of its import tariff on the foreign export industry.

This argument indicates that the trade-policy relationship between trading partners has a Prisoners' Dilemma structure. Governments could behave unilaterally and select high tariffs, but they would do better by agreeing to select lower tariffs. The enforcement of such an agreement is an important concern, however. This is because each government would gain from selecting a high tariff, if its trading partner's policy is held fixed. Thus, a trade agreement can be valuable as a means through which governments pursue their joint interests and negotiate lower tariffs; but the trade agreement must also include adequate enforcement provisions, as otherwise a government would be tempted to "cheat" and raise its tariff back toward the preferred unilateral level.

\footnotetext{
${ }^{4}$ For further analysis of this point, see Bagwell and Staiger (2002).
} 
A trade agreement becomes enforceable through the possibility of retaliation. Naturally, a government will refrain from cheating with a tariff increase, if it anticipates that the short-run gain in welfare is small in comparison to the long-run welfare loss that occurs once its partner undertakes a retaliatory tariff increase. Like reciprocity, retaliation is thus also a fundamental feature in the design of a trade agreement.

With this framework at hand, we now return to the issue of remedies. Our point is most easily developed through an example. Let us suppose that the government of country A raises a tariff above its negotiated binding. As a result of this action, the government of country B complains that its negotiated benefits have been nullified or impaired. The government of country A disagrees, perhaps arguing that its tariff hike is justified as a safeguard. In any event, a panel is formed, the issue is debated, and ultimately the panel finds in favor of country B. The government of country A then files an appeal, and the case proceeds to the Appellate Body. Eventually, the Appellate Body upholds the panel's finding. At this point, the government of country A must withdraw the offending measure, offer acceptable compensation, or potentially face authorized retaliation by country B. Retaliation would take the form of a withdrawal of a concession by country B, and the magnitude of the corresponding tariff increase would be commensurate in prospective value to that of the tariff increase originally undertaken by country A.

This example points to the possibility that the government of country A may violate its binding, maintain the violation for some period of time (while panel and Appellate Body decisions are being reached), and then return its tariff to the bound level. As suggested by the economic framework sketched above, the government of country A may then enjoy the benefits of cheating without facing the costs of retaliation. Furthermore, even if the offending measure were not removed, the magnitude of the retaliatory response would be scaled relative to the prospective cost of this measure. In this case, too, the government of country A effectively enjoys the short-term benefits of cheating for free.

As this discussion suggests, a dispute settlement system that relies only on prospective remedies may have weak enforcement provisions and thus encourage violations. Such a system allows a government to contemplate a tariff increase without weighing in the full cost of the tariff increase on its trading partner. A better system would be attentive to the retroactive and prospective costs that are attributable to an offending measure. In the context of the example above, the government of country A would be less inclined to raise its tariff and claim a safeguard exemption, when its case is 
weak, if the remedy system included some penalty for retroactive costs as well. More generally, a remedy system in which the magnitude of any retaliatory response is scaled relative to the retroactive and prospective costs of the offending measure may enhance the enforcement of efficient trade policies.

\section{Conclusions}

In sum, this panel report suffers first and foremost from the lack of clarity of Canada's arguments. The WTO dispute settlement system is decentralized and panels cannot move and discuss claims not properly before them (Article 6.2 of the WTO Dispute Settlement Understanding, DSU). Hence, to the extent that Canada did not advance a claim, the Panel could not ex officio move ahead and discuss it.

This particular case, however, is a bit more complicated. Some of Canada's arguments could be interpreted as moving into the thorny issue of retroactive remedies. The Panel, probably in anticipation, established a high evidentiary standard which is hardly supported by any sort of reasonable allocation of the burden of proof grounds, and thus avoided entering into this discussion.

The fact that Canada did not appeal this report is probably an indicator of the value it attached to the issue.

\section{References}

Bagwell, Kyle and Robert W. Staiger. 2002. The Economics of the World Trading System, Cambridge, MA: The MIT Press.

Mavroidis, Petros C. 2000. Remedies In The WTO: Between A Rock And A Hard Place, 11 European Journal of International Law, 763-813. 